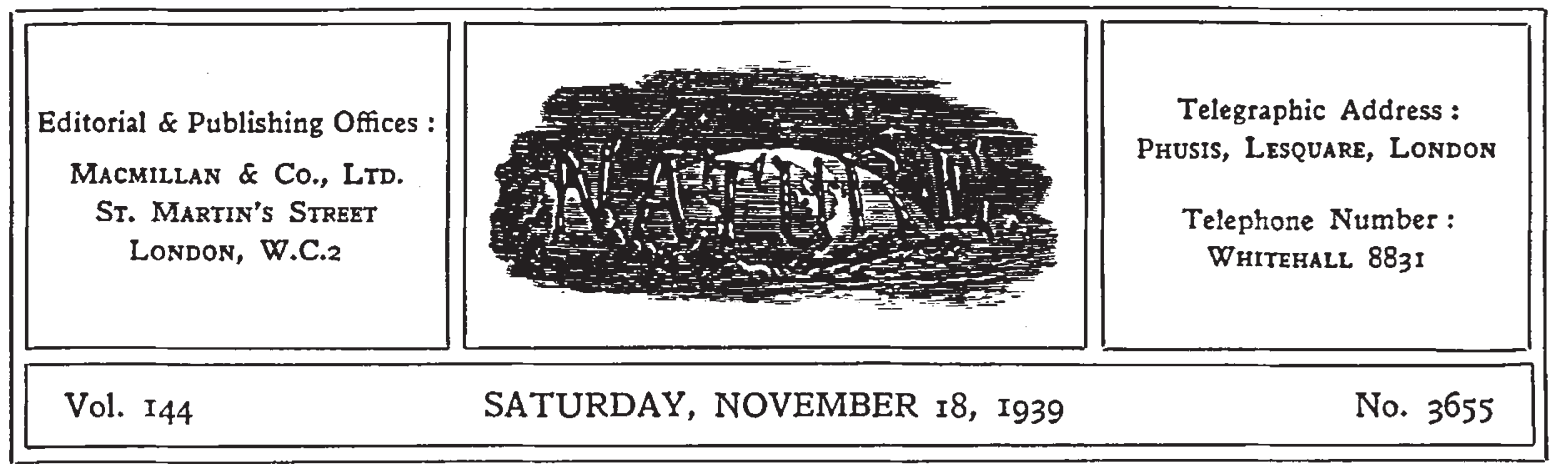

\title{
MAN-POWER AND THE NEEDS OF YOUTH
}

$\mathrm{F}$ EW features of the opening weeks of the War have received more widespread approbation than the desire manifested in our general policy to conserve human life so far as possible. If loss of life is inevitable in warfare, strategy and tactics have been designed to secure objectives with the minimum of loss, and to avoid the appalling wastage which so often characterized offensives in the War of 1914-18. The announcements that the earlier age groups will not be among those first called up for service with the armed forces and that the former militiamen are not to be drafted immediately to active service units, the fundamental idea in evacuation schemes, and even the redundancy or waste in certain branches of civil defence against air attack which have been the subject of recent criticisms, are all signs that lessons of the last war are being taken to heart. It is realized that the man-power of Great Britain is a most precious national asset, and a serious effort is being made to conserve it.

Welcome as such signs may be, we cannot assume that the lesson has been fully learned. Man-power is as precious on the home front as in the field, and the uneasiness and criticism regarding the Ministry of Supply which have found expression are indications that concern exists whether the wisest use is being made of the nation's resources in labour and skill in the mobilization of industry, to meet alike the demands of the fighting services for munitions and of the myriad essential home needs of a nation at war. Even more disquieting, however, is the postponement of the raising of the school-leaving age to fifteen years, which was to have been enforced from September 1 last.
That an Act should have been passed repealing sections one to six of the Education Act 1936 cannot be viewed without dismay. A trenchant passage in the paper by Mr. W. O. Lester Smith, director of education for Manchester, which was read before a meeting of Section L (Education) of the British Association at Dundee seems now almost like a prophetic warning :

"One of the great social tragedies of our time is our blindness to the needs of boys and girls in the adolescent period when schooldays are over. The wanton blow struck at the day-continuation school clauses of the Fisher Act by the Geddes Axe was probably the unkindest cut our educational system has suffered; it has prevented local authorities from making a decent job of the youth problem."

Mr. Lester Smith goes on to point out that, of our three million young people between the ages of fourteen and eighteen years of age, one third only attend any kind of school, another third belong to some voluntary organization, while the remaining third-probably those who need it most-are completely out of touch with educational or wholesome social influences. Mr. Lester Smith's argument is powerfully supported by Dr. A. E. Morgan's recent report to King George's Jubilee Trust on the needs of youth, where it is maintained that the raising of the school-leaving age to fifteen years is not enough. We cannot afford to let even the boy or girl of sixteen slip out of our care and allow invaluable human capital to run to waste. A system of part-time continued education carried on during the working day up to the age of eighteen years is essential.

We are indeed far as a nation from realizing the difference it would have made if the Fisher 
Act had been in force in the post-War years, or how far the shock given to our social life by the disaster of midespread unemployment might have been broken. The exasperating picture drawn by the Unemployment Board of youth going to seed after a flourishing beginning followed by lack of attention need never have been; the boys and girls whose lives were blighted by the effect of those drifting years might have found help and strength in the development of their minds. Nation and Government alike have been lacking in imaginative insight where youth is concerned. So far from recognizing the cruel wrong done by our neglect, the Government is now withdrawing the only big educational gain of this generation, and there are even those whose first reaction to the need for economy in the financial sphere is to press for the further squandering of the most precious form of our human capital. The recent announcement of the President of the Board of Education that a special committee has been set up to deal with juvenile welfare is a welcome sign, however, that the Government is not entirely indifferent to the matter.

It is recognized, of course, that under war conditions administrative arrangements necessary to make beneficial use of the extra year at school would be difficult and that the difficulties have been enhanced by evacuation. To base suspension of the raising of the school-leaving age on financial grounds, however, is reprehensible and dangerous, betraying an indifference to fundamental values that may well cause alarm among all who are concerned to see that our war-time effort is prosecuted as effectively as possible. The contention that the elaborate machinery for exemptions would be unworkable in present circumstances is equally invalid. Recognition of the real value to the nation of raising the standard of education during the formative years would lead us rather to abandon all exemptions, as indeed most educational authorities recommended originally.

It is indeed idle to expect real progress until the nation as a whole is awake to the value of youth as its ultimate capital-the bedrock upon which alone, as Dr. Morgan remarks, we can lay the foundations of real national fitness. Then indeed we might have the courage to repair this evil and not intensify it. To impose compulsory continuation education up to the age of eighteen might indeed put a strain on industry at a time when the war demands all its energy. That, however, is not the whole truth. Even more than the nation needs munitions, it needs capable and intelligent human power. So far as the immediate needs of the war are concerned, it might be true economy to take all boys and girls out of industry for some hours every week for education. Any loss in material output would be more than balanced by the improvement in the men and women on whose spirit and capacity the nation must rely for victory.

If we regard, as we must, the permanent needs of the nation, the argument is more powerful still. None can say how many of the difficulties of the last twenty years are due to the destruction of talent and virtue by the last war itself, to the loss of constructive minds, imaginatively alive to the fundamental issues. But some of the difficulties are doubtless due to our persistent indifference to the nation's larger needs, our failure to strengthen the moral and intellectual power of the electorate to meet the demands made by world politics on their intelligence and imagination.

The discussion on education as a preparation for industry and on education in industry before the British Association at Dundee afforded welcome evidence that, at least in some quarters in industry, the higher standard of education demanded in the leaders of industry, as well as in the rank and file, for the successful conduct of industry to-day is now recognized. The wider recognition of the value of a sound general education is all to the good, and equally the dependence of progress upon co-operation between industry and educational authorities is gaining recognition.

It is indeed from co-operation in this way, the development of contacts between the educationist and the industrialist, and the fuller understanding of each other's point of view, difficulties and problems that we may expect an informed opinion to emerge powerful enough to resist short-sighted policies or economies on the part of the Government. Already many industrialists are alive not only to the importance of part-time continued education, but also to the importance of provision for the leisure needs of adolescents. It is for the industrialists to join hands with the educational authorities in representations against policies likely to undermine industrial efficiency and dissipate human capital.

Dr. A. P. M. Fleming's fine presidential address to Section I of theBritish Association, a portion of which is printed elsewhere in this issue (p. 852), strikes the right note in this crisis. Industry, he contends, is not concerned with the education of its personnel in a narrow sense only. It recognizes increasingly 
that education for those engaged in industry must be characterized by broad aims and linked up with the outside world. It has proved its willingness to co-operate with education and is increasingly desirous of recruiting those well trained in fundamental principles rather than in any special branch of the selected science. It is turning its attention to the problem of finding suitable personnel trained to undertake the increasingly difficult problems of management. As this problem is solved, industry will find itself provided with leaders imbued with the realization that every industry is in fact a national service, although it may be conducted by private enterprise, and as awake to the welfare of its workers as they are to the technical efficiency of the enterprise. Such leaders will ever be vigilant against the betrayal or waste of national resources, whether in materials or in men and women. Meanwhile, it is imperative that the importance of youth as a national asset should be fully recognized, and that every effort should be made to prevent a repetition of the disastrous mistakes of the last war period in the treatment or even exploitation of youth.

\section{PSYCHOLOGY OF WAR AND PEACE}

War and Peace

Essays in Psychological Analysis. By Dr. William Brown. Pp. xvi +93 . (London: Adam and Charles Black, Ltd., 1939.) 5s. net.

$\mathrm{T}$ HIS book left its author's hands a few months before the outbreak of war, and though he was sanguine enough to say that the events at Nunich in September 1938 "saved the world from war at that time, and possibly for ever", yet his book does not on that account lose any of its real value. Dr. Brown is a well-known psychologist of a definitely marked type. He writes here as a psychologist on the subject of war and peace, and he would have done well if he had adhered rigidly to the scientific point of view, and avoided even distant references to his political convictions. The book would probably also have gained in weight and influence if greater care had been bestowed upon clear and consecutive exposition.

The book consists of six chapters, three of them selected from previous publications, together with a number of letters contributed to The Times. The author's claim that these parts in their sub. ject-matter belong together will not be disputed, but it must be added that if they are to "fall naturally into their place as stages in the argument", the reader must to a great extent make them do so. For the most part, Dr. Brown makes himself quite intelligible to people who are not students of abnormal psychology, but the reader should be warned that, after many pages free from technicalities, he is suddenly informed that "we may cure or improve the hysteric, the psychoneurotic, but the psychotic still in the main escapes us".

We have said so much because we believe that the psychologist has an important message on the subject of war and peace, and because we are anxious that he should be understood by the ordinary intelligent citizen. Dr. Brown holds that unless the world applies psychology to its problems, as it has applied physics and chemistry, physiology and pathology, its pursuit of peace will continue to fail. His difficulty is that the man in the street thinks he knows all about psychology, as he thinks he knows all about economics-for has he not a mind of his own, and has he not much to do with credit balances and deficits? We cannot have a nation of experts, but we ought to have a far wider appreciation of the forces that make for war. Among the most fundamental of those forces are the tendencies to self-preservation, selfassertion or aggressiveness, acquisitiveness, and pugnacity. The activity of the group mind, with partial liberation of repressed mental forces, especially under the influence of a leader, also stands out as an essential factor in leading to the outbreak of war. Such are the main positions taken up and explained in Dr. Brown's book.

If we interpret Dr. Brown aright, he would say that in spite of all that has happened since this book appeared, his views remain unchanged. When tho war ends, we must begin again to seek peace and ensue it, never yielding to a belief that war is inevitable. But, he holds, we shall never secure peace by orgies of pacifist sentiment. The more hopeful way is that of understanding human nature, especially those sinister forces which lurk in the unconscious of the best of us. "The tiger is there, and the wolf, and the jackal, and the snake, and we must not forget the donkey."

We conclude by expressing the hope that psychologists of different schools will do much more than has yet been done to throw light on the dark problems of war. Meantime, Dr. Brown has courageously led the way. 